\title{
PARADES OF MONUMENTS AND MEMORIALS: TRANSFORMATION OF MEMORY, PLACE AND IDENTITY IN A SLOVAK CITY'
}

Original scientific paper Submitted: 1. 7. 2018 Accepted: 6. 9. 2018.

DOI: $10.15176 /$ vol55no207

UDK 39:316.334.56 $71-027.555$

72:316(439.22Banská Bystrica)

\section{ALEXANDRA BITUŠíKOVÁ \\ Matej Bel University in Banská Bystrica, Faculty of Arts, Department of Social Studies and Ethnology, Banská Bystrica}

\begin{abstract}
The paper focuses on monuments and memorials construction, reconstruction, removal or relocation in Slovakia in the context of post-socialist urban development. It focuses on monuments and memorials illustrated by a set of examples and narratives from the city of Banská Bystrica. Monuments are built structures erected to commemorate an event or a person of historical importance. As significant landmarks they are an important part of city-making, but often also carry a political message. The post-socialist reinterpretation of the past, confrontation with the legacy of several political regimes, particularly communism, reveals its traces in the urban landscape of Banská Bystrica and reflects the constant contestation over urban space and its representations.
\end{abstract}

Keywords: city, monuments and memorials, post-socialism, Banská Bystrica, Slovakia

\section{INTRODUCTION}

Monuments and memorials in post-socialist cities have become a popular object of urban research in the last decades. As Verdery stressed, tearing down and erecting statues is

${ }^{1}$ The title was inspired by Katherine Verdery's book The political lives of dead bodies (1999) who has written about transformations of statues and monuments as "parades of dead bodies". The paper has been supported by grant no 1/0074/16: Slovenské mesto $v$ 21. storoči v kontexte nových rozvojových trendov: etnologická perspektiva (The Slovak city in the $21^{\text {st }}$ century in the context of new developmental trends: ethnological perspective). 
obviously not unique for the post-socialist world, what is specific here is their sheer number reflecting the magnitude of the changes (Verdery 1999: 6). Different disciplines have studied monuments and memorials from different perspectives: art historians explore their aesthetic and historical values, human geographers look at them as tools to legitimise the power of political elites. Sociology and social anthropology have mostly investigated commemorative and symbolic functions of monuments and memorials, focusing on practices and narratives of commemoration (Bellentani - Panico 2016: 29). Numerous sociologists and social anthropologists have contributed to research on post-socialist urban space, monuments, memorials and memory policies (De Soto 1996; James 1999; Verdery 1999; Czepczyński 2008, 2010; Bartetzky 2010; Lisiak 2010; Darieva - Kaschuba 2012; Begič and Mraovič 2014 and others). Slovakia has often been left out of these studies, and so have been small peripheral cities, because research mostly focused on capitals or large cities of Central, Eastern and South-Eastern Europe. This study seeks to fill this gap, at least to some extent.

Setha M. Low significantly contributed to researching urban space and theorising the topic (e.g. Low 1996, 2000, 2005, 2014, 2017; Low and Smith 2006; Low and LawrenceZuniga 2003). Low's perspective on social construction and social production of space in the city is equally useful for the study of monuments and memorials in the post-socialist context. Low defines social production as the processes responsible for the physical creation of space that combine social, economic, ideological, and technological factors (Low 2014: 35). This can be understood as primarily relating to processes which are governed from above (top-down) and which shape the social production of a public space. Indeed, in case of monuments and memorials, it is usually the state, municipal or regional authorities who order, sponsor and manage erecting new monuments in the city. In most cases they represent what should be or has to be remembered by the official state ideology (Crinson 2005: xvi). Monuments and memorials are erected with the aim to legitimise political power and to define a "new" symbolic urban landscape, to contribute to city-making and identity-forming, and to promote selective and dominant historical narratives (Bellentani and Panico 2016: 37). In the end, all approaches to memory politics connected to monuments and memorials are governed primarily by the governing municipal, regional or state authorities. Social construction, on the other hand, "defines the experience of space through which 'peoples' social exchanges, memories, images and daily use of the material setting' transform it and give it meaning" (Low and Lawrence-Zuniga 2003: 20; Low 2000: 128). This perspective addresses the question of how monuments and memorials are understood, interpreted and re-interpreted, remembered or forgotten by different groups of the urban population.

Monuments and memorials as the most obvious built symbols of collective memory have been objects of constant negotiation and contestation in any society or any political regime. Maurice Halbwachs was one of the first scholars who stressed that the past was reflected and preserved in the built environment - a repository of conscious and uncon- 
scious collective memories (Halbwachs 1992). Because monuments and memorials are closely linked to remembering, it is not surprising that in times of major political changes (such as the end of communism, for example) "entire landscapes are symbolically unmade and remade to influence collective memory and the process of remembering" (Begić and Mraović 2014: 25). Indeed, the introduction of new symbols and the erection of new monuments and memorials has been accompanied or followed by the removal, reconstruction or relocation of monuments built by communist elites.

The following case study of the city of Banska Bystrica is a qualitative ethnographic study (face-to-face interviews with local inhabitants and city representatives, and participant observation), combined with the analysis of regional newspapers, journals, memoirs and archival documents. It covers the period of nearly three decades of post-socialist urban transformation, since the political change in 1989.

\section{BANSKÁ BYSTRICA: (ANOTHER) CONTESTED POST-SOCIALIST CITY}

Banská Bystrica is a medium-size city of almost eighty thousand inhabitants, situated in a mountainous region of Central Slovakia. Its history dates back to 1255 when it was granted royal municipal and mining privileges by the Hungarian ruler Béla IV. Rich silver and copper deposits and extensive mining sustained dynamic development of the city in the Middle Ages. In the fourteenth and fifteenth centuries, "the copper Banská Bystrica" flourished as an important European mining centre with a strong German influence. The medieval city, like other European cities developed, its economic strength from trade. The "Golden Age" of the mining city lasted until the seventeenth century, and after that the city became a centre of crafts, commerce and services. The city witnessed its most turbulent period in the $20^{\text {th }}$ century: its inhabitants experienced seven political regimes and states ${ }^{2}$ that had a strong impact on their memories and identities, their remembering and forgetting. The most important part of the city's $20^{\text {th }}$ century history was the Slovak National Uprising. The uprising was the largest anti-Nazi resistance movement in Central Europe, which started on 29 August 1944 in Banská Bystrica. It was based on a partisan battle and involved partisans from around 30 countries. Despite its cruel suppression by the Nazis in the late autumn of 1944, it remains one of the most important parts of Slovakia's modern history. However, during communism the story of the uprising was "stolen" by the Communist Party as "the communist" uprising and was celebrated annually in Banská Bystrica as a national communist commemorative event. Its true meaning based on historic facts

\footnotetext{
2 Seven different political regimes include: the Austro-Hungarian Empire, the democratic state of the first Czechoslovak Republic, the fascist Slovak State, the post-war Czechoslovak Republic, the federal Czechoslovak Socialist Republic, the post-communist Czecho-Slovak Republic, and the Slovak Republic since 2003.
} 
(the uprising built on a broad international coalition against the Nazis) was given back to the narrative only after 1989. It took at least ten years to restore and strengthen the symbolic significance of the historical event in the collective local and national memory.

Constant reinterpretation of the past, confrontation with the legacy of several political regimes, particularly communism, and forming new symbols and meanings after the 1989 fall of communism is visibly reflected in the urban landscape. Symbolic control of space and its representations in the form of monuments and memorials has become part of active contestation (Low 2005: 10) as described later. The following parts of the paper are mainly built on the local narratives that reflect various expressions of group contestation over the urban space and its representations, symbols, monuments and memorials.

\section{PARADES OF MONUMENTS AND MEMORIALS AS OBJECTS OF REPRESENTATION}

Monuments, statues, memorials or plaques are physical symbols of collective memory. They are expected to commemorate the events or personalities that are important for certain groups or communities in a city. Moreover, monuments and memorials are "parts of the city landscape, spatial points of reference or elements founding the identity of the place [...]" (Caves 2005: 470). Banská Bystrica has witnessed several deaths, rebirths or parades of its monuments and can offer a number of urban narratives demonstrating these processes. They are based on the ethnography of urban space transformations, reflecting the contestation of symbolic meanings of representations of various political, social and cultural groups in the city. ${ }^{3}$

\section{DEATH AND REBIRTH OF VIRGIN MARY}

For 245 years now, the dominant and much-loved symbol in the upper part of Banská Bistrica's central square 4 has been the Baroque Marian column dedicated to Virgin Mary, built after a devastating plague in 1719. In 1964, local communist leaders took a step towards what Czepczyński calls landscape cleansing (Czepczyński 2008): they decided to remove the monument from its original site on the central square and to transfer it to an

\footnotetext{
${ }^{3}$ Also see Bitušíková 2009.

${ }^{4}$ The square has been called The Square of the Slovak National Uprising since 1949. In its long history it carried different names, such as the German Ring, (since the beginning of the city to 1896 - more than 500 years); to the Hungarian IV. Béla Király Tér in 1896-1919; to Slovak names of Hlavné námestie (Central Square); Masarykovo námestie (Masaryk Square); Námestie Andreja Hlinku (Andrej Hlinka Square) in 1919-1949.
} 
"invisible" corner in a nearby castle area. The reason for the relocation was highly political: the Soviet leader Nikita Khrushchev was expected to visit the city for the celebration of the Slovak National Uprising. Local communists considered it inappropriate to keep a religious symbol on the central square. As a local witness expressed in his memoirs, the Marian column would "damage photographic and film images that would go to the whole world, not only the socialist world. The highest representative of the Soviet Union waving from a platform would look ridiculous under the statue of Virgin Mary" (Magula 2012: 64). As a result, the column was relocated (but not destroyed) and replaced by a wooden platform for Khrushchev. Paradoxically, the political decision had a positive (involuntary) outcome. Relocating the column from a busy and polluted square (at the time) to a quiet out-of-the-way place helped its protection. It was only in 1994 under the local government of the first post-communist mayor (a progressive architect) when the square was turned into a pedestrian area and the column was transferred back to its original place on the central square, attracting widespread media and public attention. After thirty years in exile, the Baroque column had become the central monument of the square once again, as well as a popular new meeting point (called "at the Virgin Mary" or "at the column").

Additionally, the column has been gradually acquiring a new function. It has become the key place of commemoration in times of democratic public protests, demonstrations or gatherings. For instance, in recent years people have been gathering and lighting candles on the steps of the column at times of local, national or global tragic events or - more often - if democracy in the country was threatened. These were the cases of the victory of a Neo-Nazi as a governor of the region in 2013, the murder of a Slovak journalist in February 2018 and the murder of a foreigner who tried to protect women in a bar in Bratislava in June 2018. These events, particularly the second one (the murder of an investigative journalist who uncovered connections between the government and mafia) stirred significant parts of the Slovak society, including many young people who started a new civic movement "For a Decent Slovakia" in 2018, which led to the resignation of the Prime Minister. The column of the Virgin Mary in Banská Bystrica has thus been not merely a landmark, but has become a meeting point as well as a highly contested place of expression of opinions of diverse groups regardless of their religious beliefs. It is now an important and accepted symbolic space and place of gathering to defend democracy for citizens who cherish democratic and human rights values (although attempts to discredit the space and events organized around it are constant - mainly on the social media). 


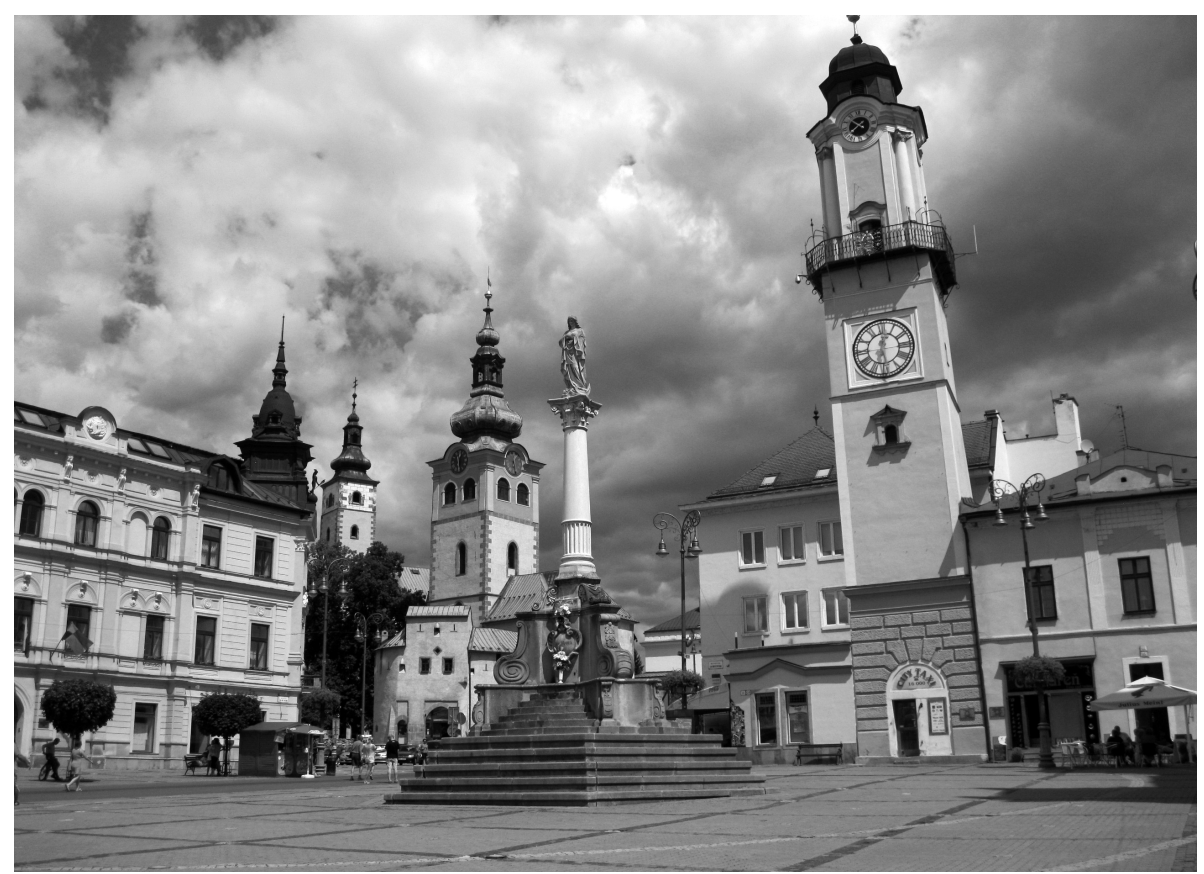

Picture 1: The Marian column back on the main square, photo: A. Bitusikova, 2013

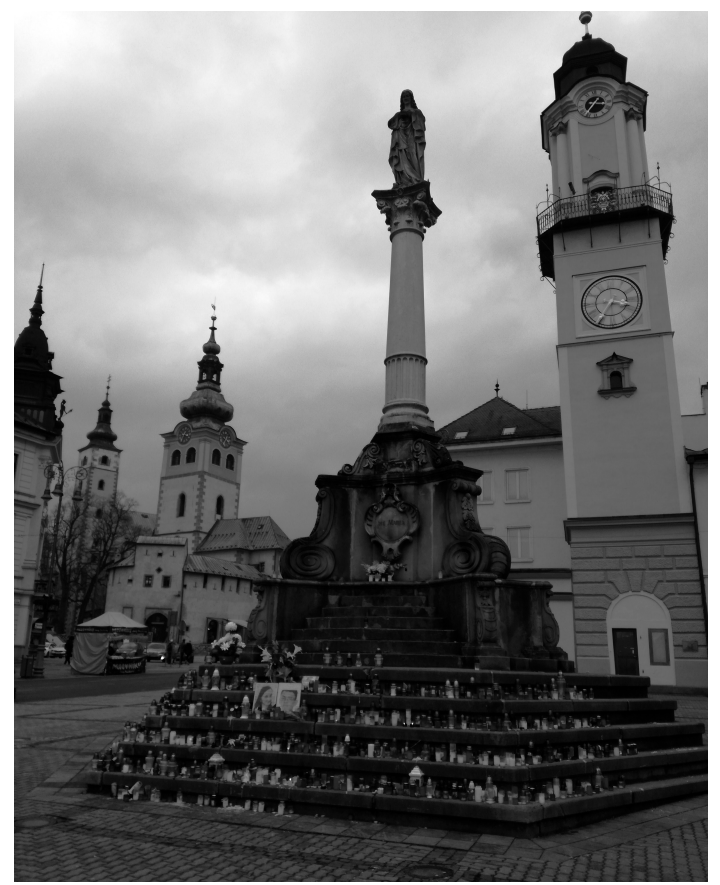

Picture 2: The Marian column as a place of commemoration, photo: A. Bitusikova, 2018 
Despite the column's strong historical and religious meaning, its contemporary meaning has been dominated by a power of democratic values - at least at times of any societal or political crisis. The Virgin Mary column is an example of a contested monument with a number of different narratives that might reflect memoirs across different generations and different social, religious, ethnic and other groups.

\section{THE BATTLE BETWEEN THE FOUNTAIN AND THE OBELISK}

Another urban narrative reflecting contested space in Banská Bystrica is connected with an Art Nouveau fountain situated in the centre of the main square. It had been a source of local pride especially in the inter-war period when it was described as an innovative colourfully illuminated urban public space and attraction (1918-1938). Theodor Karas, the chief architect of the city in the 1940s, shared his memories with me in his unpublished memoirs:

One day shortly after the liberation I was called to the Mayor's office. A Russian general was present there. The Mayor was angry because the General ordered the demolition of the fountain and its replacement by a new memorial - an obelisk to commemorate the liberator - the Red Army... The General strongly insisted on his proposal, but the Mayor tried to defend his position to build the obelisk somewhere else and to save the fountain... I asked for permission to talk to the designer of the obelisk proposal, a Russian Captain... He told me that the General would never agree to any other location but the center of the square. Then I said in despair: "The fountain means as much to Banská Bystrica as does the Eiffel Tower to Paris!"... And this sentence saved the fountain which is a special feature of Banská Bystrica until today. ${ }^{5}$

The black obelisk made of marble imported from the Soviet Union and dedicated to the liberators of the city in World War II was eventually built in the lower part of the central square (below the fountain). During socialism, every year on the 25 March (the Liberation Day of the city), a military parade was organised at the obelisk, with mandatory participation of the public (especially primary and secondary schools). The inscription on the obelisk mentioned the Soviet Red Army as the only liberator of the city, ignoring the historical role of the Romanian Army that equally contributed to the liberation. There is no written evidence why the Romanian Army was not mentioned as the liberation army ally on the obelisk, we can only assume that it was because of Soviet dominance in any narrative at the time, with the WW2 narrative definitely one of them. A new additional inscription with the correct information also commemorating the heroic role of the Romanian Army in the liberation of the city was placed on the obelisk only in the early 1990s. This fact shows that the obelisk has been an object of a power and ideological struggle since its erection.

${ }^{5}$ From personal correspondence with Theodor Karas; the archives of the author. 


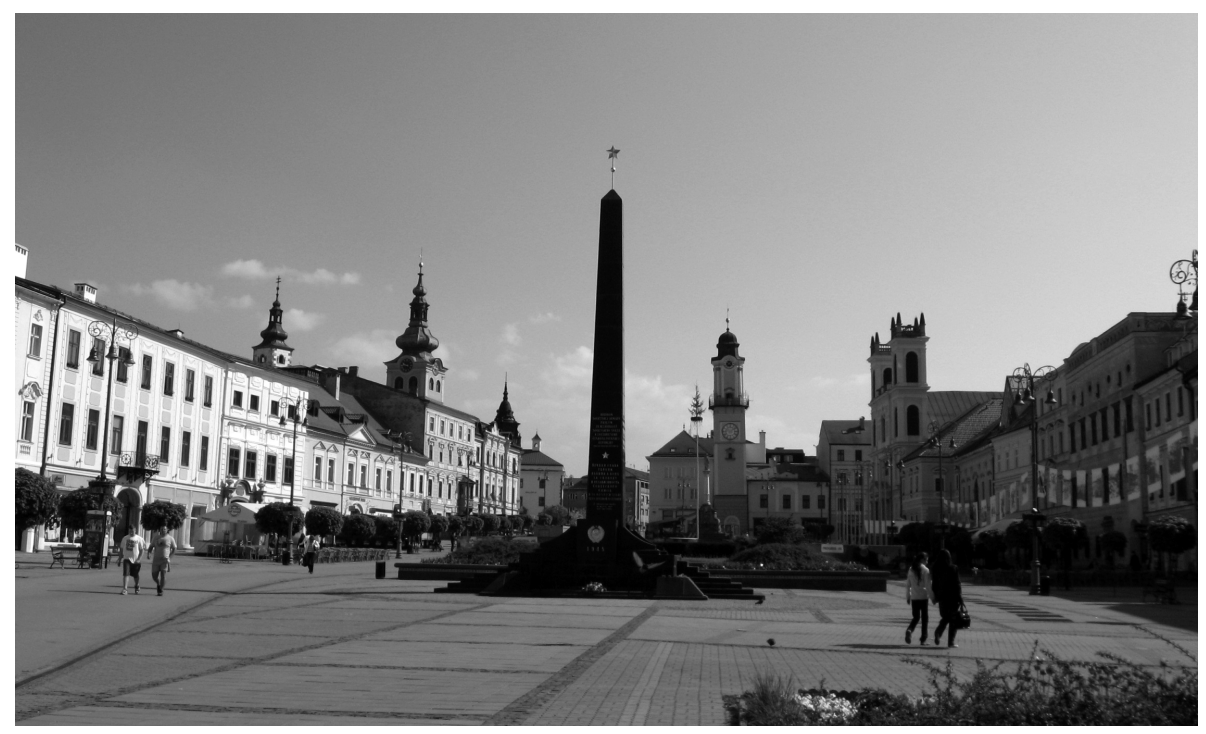

Picture 3: The obelisk, photo: A. Bitusikova, 2015

The contestation of the obelisk was further reflected during the reconstruction of the central square in 1994. The new square design included a plan to transfer the obelisk from the main square to a place in a nearby quiet remembrance area of the Museum of the Slovak National Uprising. The proposal was met with strong protests from the representatives of The Anti-Fascist Fighters' Union (former partisans during the Slovak National Uprising) who saw the relocation from the central square to a marginal square as an act of disrespect toward them. In the end, the obelisk was not relocated: it is still situated on the historic central square and it represents another example of a symbol that reflects diverse collective memories and identities. It is a commemorative object that has different constructivist meanings, allocated to it by different groups of local residents. As Czepczyński stresses, "groups of young people use a distinctly different system of representation from that of the older generation, so places and urban features might have separate constructivist meanings for them" (Czepczyński 2010: 29).

According to all interviews and observations, the obelisk monument is of great value and is a point of identity construction for the oldest citizens, mainly those who were actively involved in the anti-Nazi partisan battle of 1944, and were celebrated as heroes by the Communist Party during all of their lives. ${ }^{6}$ These people see the obelisk as a symbol of their fierce battle against Nazism and the final victory in 1945.

${ }^{6}$ The Slovak National Uprising, the largest anti-Nazi resistance movement in Central Europe, which started on 29 August 1944 in Banská Bystrica, involved partisans from about 30 countries. Banská Bystrica was the centre of the uprising, and this historic event is now seen as the most important part of modern history of Slovakia and its identity building. However, in the communist past, the uprising was "stolen" in 
For the post-war generation, the obelisk is a symbol of the communist ideology and oppression, and it invokes memories of mandatory annual parades organised by the Communist Party.

For the youngest generation born after 1989, the monument does not carry any political or ideological meanings and it is just a common meeting point without any positive or negative connotation.

The main explanation of different constructivist meanings given to the monument is that the city of Banská Bystrica as the centre of the Slovak National Uprising in 1944 has been building its identity on this event, demonstrating the importance of joint efforts of many countries to fight against Nazism. The dominant communist (Soviet) narrative of the Slovak National Uprising emphasised the crucial role of the Soviet Red Army in the uprising and in liberating the city, ignoring the international character of the uprising. In addition, the power of the civic anti-Fascist local movement was totally neglected, unrecognised and silenced in this narrative. However, local partisans who were active in the uprising were celebrated as communist heroes and enjoyed a number of special social and financial benefits (according to a law called 255). It is therefore not surprising that the understanding of the Slovak National Uprising is different among various population groups (mainly based on pro- or anti-communist statements) and it has become nationally more accepted only after the fall of communism when real facts and stories about the uprising were publicly presented without any ideological falsification.

To sum up, the commemoration of the bottom-up constructed Slovak National Uprising has played and still plays a much more important role in the identity formation in the city of Banská Bystrica and Slovakia than the commemorations and memorials dedicated to the liberating Soviet (and Romanian) Army. The commemorative event dedicated to the Slovak National Uprising (29 August) is annually visited by thousands of visitors from all over Slovakia and abroad, unlike any commemorations dedicated to the liberation of the city organised at the obelisk memorial. The fact that the Slovak National Uprising plays an important role in identity formation all over Slovakia has also been confirmed in a recent survey conducted by the Institute of Public Affairs in Slovakia and the Institute of Sociology of the Academy of Sciences of the Czech Republic. According to the survey, the Slovaks consider the Slovak National Uprising as the most important positive event of Slovakia's modern history in the 20th and the 21st century, followed by the establishment of the independent Slovak Republic in 1993 and the Velvet Revolution in 1989.?

all discourses by the Communist Party as "their" event, and therefore, there are still many tensions and ideological misunderstandings regarding the uprising across various, especially older groups of citizens.

7 https://dennikn.sk/1201147/okupaciu-odsudzujeme-k-tomu-co-prislo-po-tom-sme-zhovievavi; accessed on 20 August 2018. 


\section{DEPARTURE OF DEAD BODIES: HANG LENIN!}

Katherine Verdery describes statues as "dead people cast in bronze or carved in stone" (Verdery 1999: 5). She continues to say that statues can bring a person into the realm of the sacred or an icon. Tearing a statue down or raising up a new one can reverse the process of sacralizing or resacralizing persons who had been unnoticed, ignored or unremarked (Verdery 1999: 5).

The most visible demonstration of post-socialist change in hundreds or even thousand cities of Central, Eastern and South-Eastern Europe was the removal of the statue of Lenin.

The statue of Vladimir llich Lenin - the central figure of communism - appeared in almost every socialist city. In Banská Bystrica, the statue was situated (not surprisingly) on Lenin's Square (now Freedom Square). Its rather late erection in 1973 was preceded by nearly a decade of preparations and discussions about the final design of the statue, made by architect Jozef Chrobák and academic sculptor Miroslav Ksandra. The process took long because the communist censors (members of the so called Art Committee) were never satisfied with various versions of the design proposal and could not reach a consensus on the final design of the statue: at first they did not agree with the length of Lenin's coat, later they did not like his cap, the material, the position of Lenin's hands, and even the way his shoe laces were tied... (Hámor 1990; Krajčovič 1990). ${ }^{8}$ When the statue was finally approved and erected, it only survived 17 years. On 1 April 1990 - April Fools' Day, university students organised a happening at the Lenin's statue with the aim to remind the city representatives of the fact that it was still there, 5 months after the fall of communism. The students climbed the statue, hugging it and shouting slogans such as "We will not give you up", while flying the banner "April Fools' Day". Finally, the Lenin's statue was removed in the presence of hundreds of people on 17 May 1990. As one of them remembers: "There was a large crowd of people there, very curious and excited. After the crane arrived, three workers placed a steel rope around Lenin's neck, and the statue was taken away. The crowd started loud ovations. People shouted: Hang him. Hang him. Well done. That's it..." (man, 1977). Bronze statue of Lenin disappeared. Forever. Even today no evidence has been uncovered as to where it was moved, or how, or whether it was destroyed. Still, after more than 25 years since the departure of Lenin's statue, its marble pedestal still remains, and people of all generations call the place "u Lenina" (at Lenin's). According to Czepczyński, empty pedestals silently speak of the recent past. The message of these places can be only understood by those who still remember (Czepczyński 2010: 25).

In the last two decades, the empty pedestal has been used as a training area for skaters or as an open space for sprayers. Moreover, from time to time it has attracted the attention of young artists (mainly students or graduates of the local Arts Academy) who do not have any specific memories of the space and see it as a good opportunity for expressing their creative ideas - mainly meant as protest or fun. They created several temporary artistic

${ }^{8}$ Although the reasons for not accepting the design proposal of the Lenin's statue seem totally bizarre today, this was how "small" local communist censors operated in fear of being criticised by the authorities. 
presentations at the pedestal in the recent years, including a statue of a large sausage (1.5 tons in weight and 2 meters long food for thought that - according to the authors - brings together people and reflects the formal change of form), a big scull as a reminder of an old communist wound, or a set of miniature historical buildings representing the historic city centre. The latest artistic performance using the empty pedestal (January 2018) was created by a student of the Academy of Arts who made a temporary artistic composition with a statue of an alien and installed it at the empty pedestal as his seminar course work. It took the police and media six days to find out who erected the statue, and to remove it. The author who was finally found and interviewed, said: "I saw the pedestal as a public space with a history that one can work with. It was meant to ironize the political situation in Slovakia... A symbolic alien shows his/her hand as a gesture of making peace..." ${ }^{9}$

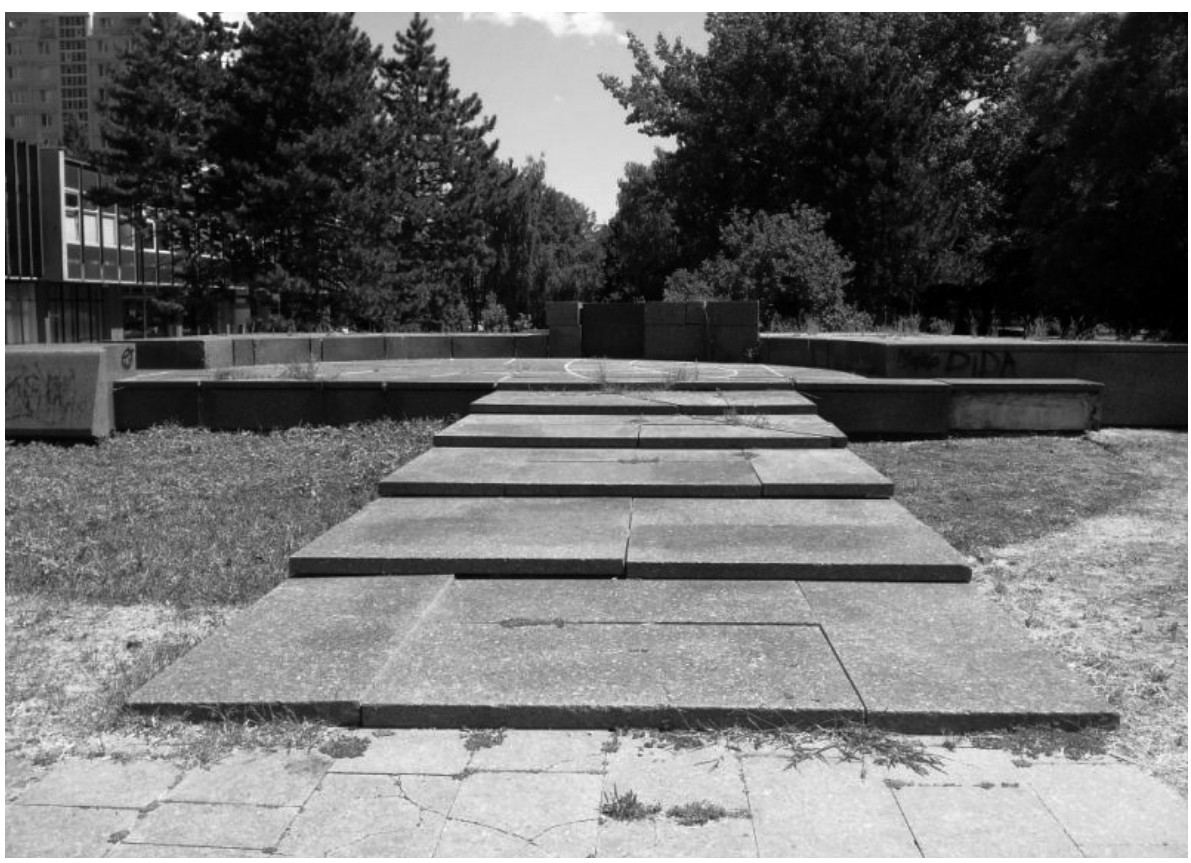

Picture 4: The empty pedestal of the Lenin's statue, photo: A. Bitusikova, 2014

These examples demonstrate that old communist symbols and icons have been slowly forgotten, but their shadows (mainly in the form of empty pedestals) are still present in the local memory and even local topography. They are constantly re-interpreted and replaced by new symbols and meanings, especially if local authorities have not decided what to do with these empty symbolic spaces.

${ }^{9}$ Záhada sochy vyriešená. TV Hronka. 10 January 2018. Downloaded from: https://www.youtube.com/ watch?v=-WWPgZPy3N4 


\section{THE VICTIMS WARN}

Banská Bystrica is the seat of the Museum of the Slovak National Uprising, situated near the city centre. The museum has a large remembrance park and an outdoor exhibition of military vehicles. In 1969, a monumental bronze sculpture (8 meters, 14 tons) called "The Victims Warn" was erected at the entrance to the museum. It is a unique monument - a silent, but powerful condemnation of the war made by Jozef Jankovič that is considered one of the ten best sculptures created during socialism. As a respondent stated: "What Picasso's Guernica means to the world, Jankovič's sculpture means to us." Despite the high artistic and symbolic value of the sculpture, the monument did not remain in front of the museum for long. In the period of the so called "normalisation" after the suppression of the Prague Spring, ${ }^{10}$ Jozef Jankovič condemned the Soviet invasion and was no longer allowed to publicly present his art. In 1972, the monument was removed to a storage of building materials in a nearby village and replaced by a large hammer and sickle. The official reason for the removal introduced by the communist authorities was that the monument was too scary for museum visitors. The communists made a few attempts to destroy the sculpture (it was supposed to be melted), but several conservationists managed to save it and in 1974 it was re-installed in the village of Kalište - a place which was burnt by the Nazis during WW2." However, the name of Jozef Jankovič had been deleted from all books and brochures for many years. The monument returned to its original place - the entrance to the museum - in 2004, and serves as a honourable commemoration place that communicates its clear meaning: the condemnation of any war and respect for the victims of WW2 (including Jews and Roma).

The sculpture "The Victims Warn" is an example of another kind of manipulation of monuments in the totalitarian regime. It was not only the symbolism and the meaning of the monument which was questioned by the communists. The reason why the monument had to be removed from one place to another (or be destroyed in many cases) was the political statement of the sculptor that was not in line with the Communist Party's narrative. The urban landscape and its representations written in symbols, monuments and memorials reflect not only history, but also power and control. The story of the sculpture is a representative example of it.

\footnotetext{
${ }^{10}$ Prague Spring - a period of liberalization in socialist Czechoslovakia that started in January 1968. It was an attempt to reform socialism, which ended on 21 August 1968 by the military invasion of the Soviet Union and other armies of the Warsaw Pact. After this period during the process of the so-called normalization many people who did not openly support the Soviet invasion (called "brotherly aid" by the communists) lost their jobs and could not continue working in their professions (mainly in the culture, arts, education, science).

${ }^{11}$ According to the former director of the Monument Institute, he and his colleagues had to use various strategies to persuade the communist authorities not to destroy the monument and to at least move it to a less visible place in the village of Kalište; https://mybystrica.sme.sk/c/20555243/obete-varuju-putujuce-susosie-sa-zdalo-sudruhom-pesimisticke.html
} 


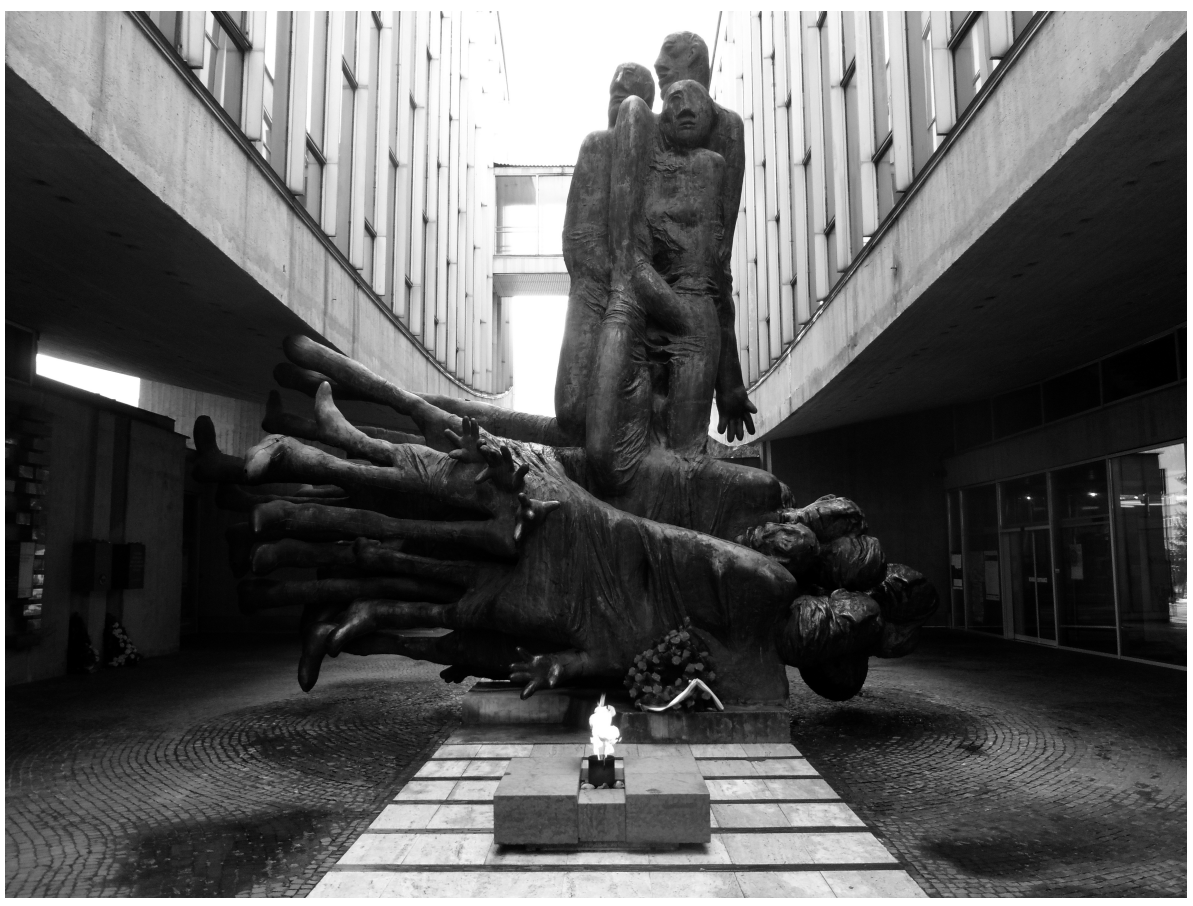

Picture 5: The victims warn, photo: A. Bitusikova, 2018

\section{ARRIVAL OF NEW BODIES}

In addition to Verdery's "parade of dead bodies" (Verdery 1999) and the removal of old monuments and symbols, a new era always provides a chance for the arrival of new ones. Political elites erect monuments in order to protect selected historical narratives that focus on convenient events and individuals while obliterating what is discomforting (Bellentani and Panico 2016: 28).

In a number of postsocialist cities, religious symbols that were forbidden or hidden during socialism started to reappear. As Czepczyński stresses, this did not happen in all the countries of the region. It could be seen mainly in the regions and countries with Roman-Catholicism as a strong religion such as Poland, Bulgaria, Romania (Czepczyński 2008: 166) - and we can also add Slovakia to the list.

In Banská Bystrica, the empty space in the castle area that remained after the removal of the Virgin Mary column to its original place on the central square inspired a number of people and groups as to how to use this space. The first symbolic and political battle over the space started in the early 1990s in the period of renaming public spaces - streets and squares. At the time the square bore the name of the WW2 liberator - the Red Army Square (Námestie Červenej Armády). In 1990, an expert committee responsible for renaming 
public spaces (appointed by the mayor) proposed a new name for the square - The Miners' Uprising Square (Námestie Baníckeho povstania) which referred to an important milestone in the medieval "golden" history of the city (1525-1526). The day after the new street signs were installed on all square corners, the City Council suddenly cancelled the expert committee's decision and from the very next day new signs were installed carrying the name Štefan Moyses Square (Námestie Štefana Moysesa), after the Roman-Catholic bishop and the first chairman of Matica slovenská. ${ }^{2}$ The head of the expert committee published a protest note against the sudden decision in a local newspaper and also sent a letter to the mayor. The response from the municipality (without giving any evidence) stated that the change was made because of protests of citizens who lived on the square. In fact, there were no residential buildings on the square, and it was the Roman-Catholic Bishop's Office that intervened in this case and managed to enforce the change of the square's name.

The contestation over the public space and its representations continued a few years later, following the challenge of filling the empty space that remained after the removal of the Virgin Mary column. After numerous negotiations and conflicts between the municipality, the Catholic Church and the Protestant (Lutheran) Church, in 2005 the empty space was filled by a new sculpture representing Štefan Moyses and Karol Kuzmány - two figures from the period of the national enlightenment in the 19th century who were supposed to be seen as a symbol of the city's ecumenism..$^{13}$ The final decision was the result of a compromise of all parties, however the statue of the two religious leaders has not been met with great enthusiasm in the public. Its artistic value has been highly criticised within the professional artistic community. The statue has also not been accepted by the urban community - it is more a source of public ridicule as it is called "the bottle opener" by the local people (due to its design).

Another new religious symbol was erected in the nearby Kapitulská Street (part of the historic city centre) in 2004: the statue of Pope John Paul II. It was created to commemorate the Pope's visit to the city in 2003. Despite the fact that it is situated in the historic central area of the city, most local citizens do not know about it, and the statute has not become a symbolic place of remembrance. In the long-term urban development strategies, a large crucifix on top of the local hill, Urpin, was also planned, however this idea has not garnered sufficient support in the City Council and was not welcomed by many citizens. Yet, it is evident that after years of suppressed freedom of faith and religion during communism, religious symbolism has been coming back to the city, which is not always accepted by the entire urban population, and sometimes - again - reflects a contested space - tensions between different political, religious and civil groups.

\footnotetext{
${ }^{12}$ Matica slovenská - the cultural institution of the Slovaks established in the 19th century - in the period of national enlightenment

13 Two men represented two dominant religions in the city and the country: Roman-Catholicism and Protestantism.
} 


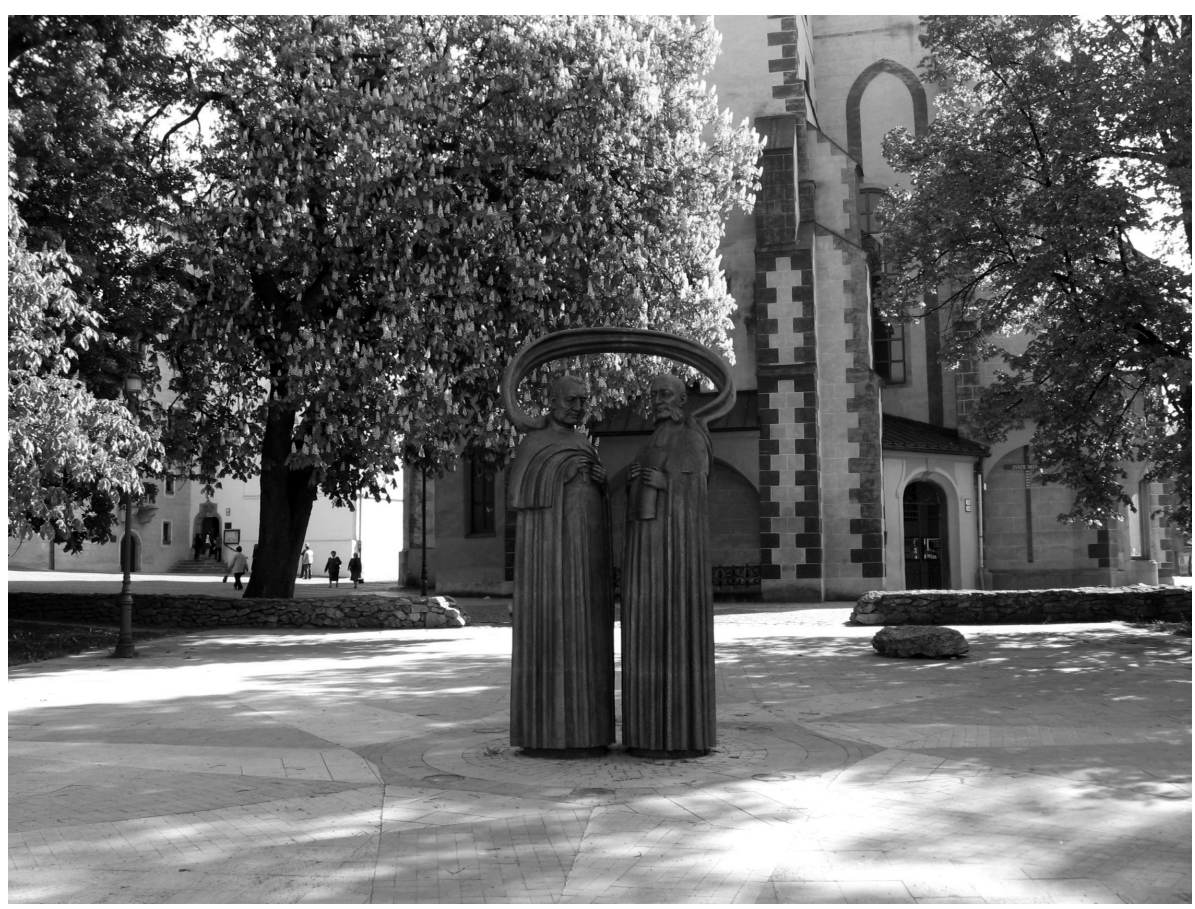

Picture 6: Stefan Moyes and Karol Kuzmany - symbol of ecumenism (or bottle opener), photo: A. Bitusikova, 2016

\section{A LONG-HAIRED DISSIDENT}

One of the examples of fierce struggle over the power and collective post-socialist memory in Banská Bystrica was the proposal to install a memorial dedicated to Ján Langoš, one of the leading figures of the Slovak anti-communist dissent, the Minister of Interior in the post-1989 Czecho-Slovak Federative Republic Government, and the founder and first director of the Nation's Memory Institute. ${ }^{14}$ The proposal to erect the memorial put forward by a group of independent members of the City Council in Banská Bystrica was adopted by the council in 2007, but afterwards a number of political and civil groups (especially the then still-existing local branch of the Communist Party and the Union of Anti-Fascist Fighters) started to publicly protest against the proposal. The City Council changed its decision four times in six years until the final decision was reached to proceed

${ }^{14}$ Ján Langoš was born in Banská Bystrica and died tragically in 2007. He was a former dissident, and the founder of the Nation's Memory Institute - the institution that collects, archives and analyzes documents from the communist past including all STB archives (the State Secret Police - an equivalent of the Soviet KGB). There were thousands of people who opposed the idea of the establishment of the Institute for the fear of publishing data from their communist history and collaboration with STB. For this reason, the personality of Ján Langoš was seen as very controversial. 
with the preparation of the memorial. Numerous political and public debates and medialization of the case clearly demonstrated that Ján Langoš, "a long-haired minister" as many called him, was a persona non-grata for many people. It was mainly because of his critical attitude towards communism and his initiative to establish the Nation's Memory Institute reminding everyone of the communist and State Secret Police history that many people would rather erase from their memory.

The memorial dedicated to Ján Langoš was finally erected in 2013 in the garden of the Centre of Independent Culture called Záhrada (The Garden), run by a group of young volunteers and activists. Since then, an annual event called "Uncovering" dedicated to Ján Langoš has been organised - a series of readings and performances dedicated to the legacy of his message. The well-known, but important inscription on the monument "Those who do not remember the past are condemned to repeat it" clearly addresses the topic of remembering and forgetting in the context of (any and not only) post-socialist Slovak city.

\section{CONCLUSIONS}

The struggle for memory and identity in the post-socialist city of Banská Bystrica reflects similar struggles in other Central, Eastern and South-Eastern European cities. It is only narratives and oral histories that differentiate one city from another, stories that produce and reproduce the past in a particular urban environment and bring it to the present.

Experience from totalitarian regimes shows that monuments and memorials reflected in collective memory may often become a tool of contestation, manipulation and power games. Facts and figures are rewritten, changed, erased or silenced in order to strengthen the collective identity of certain power groups or to mobilize people against an enemy or opposition. Official institutions, particularly representatives of local authorities, try to reinterpret history and strengthen the feeling of collective (local) identity by reconstructing and re- or de-commemorating public spaces and symbols, introducing new names, or removing, relocating and erecting monuments and memorials.

In this paper, I primarily examined the practices of removing, relocating or erecting monuments in the Slovak city of Banská Bystrica. I presented a number of narratives that demonstrate the power struggles in the city, which use memory and identity as a tool for gaining symbolic ownership over certain parts of history. The presented examples showed various strategies and approaches of the local authorities and local people toward monuments and memorials: different ways of interpreting and re-interpreting the past, of using and reusing monuments and memorials in collective memory, identity and narratives of various groups. It seems that in the case of Banská Bystrica, the removal and relocation of "unwanted" monuments and memorials has been the most common strategy, which can be seen as less devastating than a total destruction of old symbols. We can only 
assume why this was the case. Smaller cities and towns live in a shadow of big cities and big politics. Local relationships during communism were often based on all kinds of small corruption, which could result in unexpected solutions that are difficult to explain these days. The sculpture "The Victims Warn" is a typical example of the complicated transformations and bizarre political games.

\section{REFERENCES AND SOURCES}

Bartetzky, Arnold. 2010. "A Cumbersome Heritage. Political Monuments and Buildings of the GDR in Reunited Germany". In The Post-Socialist City. Continuity and Change in Urban Space and Imagery. Alfrun Kliems and Marina Dmitrieva, eds. Berlin: Jovis Verlag, 52-65.

Begić, Sandina and Boriša Mraović. 2014. "Forsaken Monuments and Social Change. The Function of Socialist Monuments in the Post-Yugoslav Space". In Symbols that Bind, Symbols that Divide. Scott L. Moeschberger and Rebekah A. Phillips DeZalia, eds. Switzerland: Springer International Publishing, Peace Psychology Book Series, 13-37. https://doi.org/10.1007/978-3-319-05464-3_2

Bellentani, Federico and Mario Panico. 2016. "The Meanings of Monuments and Memorials. Toward a Semiotic Approach. Punctum 2/1: 28-46. https://doi.org/10.18680/hss.2016.0004

Bitušíková, Alexandra. 2009. "Zápas o pamät mesta v transformácii. príklad Banskej Bystrice” [The Conflict Regarding the Memory of a City in Transformation. The Example of Banská Bystrica]. In Pamět' města [The Memory of the City]. Jana Nosková et al., eds. Brno: Ústav etnologie AVCR, 311-332.

Caves, Roger W., ed. 2005. Encyclopedia of the City. London, New York: Routledge.

Halbwachs, Maurice. 1992. On Collective Memory. Chicago, London: The University of Chicago Press.

Crinson, Mark. 2005. "Urban Memory. An Introduction". In Urban Memory History and Amnesia in the Modern City. Mark Crinson, ed. London, New York: Routledge, xi-xx. https://doi. org/10.4324/9780203414613

Czepczyński. Mariusz. 2008. Cultural Landscapes of Post-Socialist Cities. Surrey, Burlington: Ashgate.

Czepczyński, Mariusz. 2010. "Iconic Landscape as the Representation of Societies". In The Post-Socialist City. Continuity and Change in Urban Space and Imagery. Alfrun Kliems and Marina Dmitrieva, eds. Berlin: Jovis Verlag, 16-33.

Darieva, Tsypylma, Wolfgang Kaschuba, and Melanie Krebs, eds. 2012. Urban Spaces after Socialism. Ethnographies of Public Places in Eurasian Cities. Frankfurt: Campus Verlag.

De Soto, Hermine G. 1996. "(Re)inventing Berlin. Dialectics of Power, Symbols and Pasts. 1990 - 1995".

City and Society 8: 29-49. https://doi.org/10.1525/ciso.1996.8.1.29

-eta-. 2008. "Pamätník Langošovi postavia”. Echo 3/45-46: 2.

Halbwachs, Maurice. 1980 [1925]. The Collective Memory. New York: Harper \& Row.

Hámor, Ladislav. 1990. “Aj Lenin prevracal kabáty” [Even Lenin turned his Coat]. Smer 42/238: 7.

James, Beverly. 1999. "Fencing in the Past. Budapest's Statue Park Museum". Media, Culture and Society 2: 291-311. https://doi.org/10.1177/016344399021003001

Krajčovič, Martin. 1990. "Čo urobíme s Volod'om?” [What Will We Do with Volod?]. Smer 42/109: 1.

Lisiak, Agata Anna. 2010. Urban Cultures in (Post)Colonial Central Europe. West Lafayette, Indiana: Purdue University Press.

Low, Setha M. 1996. "The Social Production and Social Construction of Public Space". American Ethnologist 23/4: 861-879. https://doi.org/10.1525/ae.1996.23.4.02a00100 
Low, Setha M. 2000. On the Plaza. The Politics of Public Space and Culture. Austin: University of Texas Press.

Low, Setha M. and Denise Lawrence-Zuniga. 2003. "Locating Culture”. In The Anthropology of Space and Place. Locating Culture. Setha M. Low and Denise Lawrence-Zuniga, eds. Oxford: Blackwell Publishing, 1-47.

Low, Setha M. 2005. "Introduction. Theorizing the City". In Theorizing the City. The New Urban Anthropology Reader. Setha M. Low, ed. New Brunswick, New Jersey, London: Rutgers University Press.

Low, Setha M. and Neil Smith. 2006. Politics of Public Space. New York, London: Routledge.

Low, Setha. M. 2014. "Spatializing Culture. An Engaged Anthropological Approach to Space and Place". In The People, Place and Space Reader. Jen Jack Gieseking and William Mangold (with Cindi Katz, Setha Low and Susan Saegert), eds. New York, London: Routledge, 34-38.

Low, Setha M. 2017. Spatializing Culture. The Ethnography of Space and Place. Abingdon, New York: Routledge.

Magula, Milan. 2012. Dve deka spomienok. [Two Quilts of Memories]. Banská Bystrica: DALI-BB.

-raj-. 1990. "Nedám si Ťa”. [I Will Not Let It]. Smer 42/72: 2.

Verdery, Katherine. 1999. The Political Lives of Dead Bodies. Reburial and Post-socialist Change. New York: Columbia University Press.

Young, Craig and Sylvia Kaczmarek. 2008. "The Socialist Past and Post-socialist Urban Identity in Central and Eastern Europe. The Case of Łódź, Poland". European Urban and Regional Studies 15/1: 53-70. https://doi.org/10.1177/0969776407081275

Záhada sochy vyriešená. TV Hronka. 10 January 2018. Available at: https://www.youtube.com/ watch?v=-WWPgZPy3N4.

\section{PARADE SPOMENIKA I SPOMEN-OBILJEŽJA: TRANSFORMACIJA PAMĆENJA, MJESTA I IDENTITETA JEDNOG GRADA U SLOVAČKOJ}

Ovaj se rad bavi izgradnjom, rekonstrukcijom i uklanjanjem ili premještanjem spomenika i spomen-obilježja u Slovačkoj u kontekstu postsocijalističkog urbanog razvoja. U radu se analizira niz primjera i narativa vezanih uz spomenike i spomen-obilježja u gradu Banská Bystrica. Spomenici su strukture koje su izgrađene u znak sjećanja na događaj ili osobu od povijesne važnosti. Riječ je o znamenitostima koje su važan dio stvaranja grada, a često nose i političke poruke. Reinterpretacija prošlosti u postsocijalizmu, suočavanje s nasljeđem nekoliko političkih režima, posebno s komunizmom, svoj odraz su našli i u urbanom krajoliku Banske Bystrice te odražavaju stalan proces osporavanja urbanog prostora i njegove reprezentacije.

Ključne riječi: grad, spomenici i spomen-obilježja, postsocijalizam, Banská Bystrica, Slovačka 